\title{
Validation of Cyanobacteriales Stanier in Gibbons and Murray 1978 as a New Order of the Kingdom Procaryotae Murray 1968, and of the Use of Neuter Plural Endings for Photobacteria and Scotobacteria classes nov. Gibbons and Murray 1978
}

\author{
Request for an Opinion
}

\author{
N. E. GIBBONS $\dagger$ AND R. G. E. MURRAY \\ Department of Microbiology and Immunology, University of Western Ontario, London, Ontario
}

The blue-green bacteria have been called by the vernacular name cyanobacteria for some time, and an order Cyanobacteriales Stanier in Gibbons and Murray 1978 seems the most appropriate name for them. Validation of this name is requested even though there is no corresponding genus in the order. As theInternational Code of Nomenclature of Bacteria, 1976 revision, does not specify specific endings for taxa above the rank of order, validation of the neuter plural nouns Photobacteria and Scotobacteria for the new classes proposed by Murray and Gibbons 1978 is requested.

Recently, Gibbons and Murray (2) proposed a classification for the higher taxa of bacteria. The kingdom Procaryotae Murray 1968 (7) was divided into three divisions on the basis of cell wall staining reaction and biochemistry: namely, Gracilicutes and Firmacutes Gibbons and Murray 1978 and Mollicutes Edward and Freundt 1967 (1). Gracilicutes comprises organisms with gram-negative cell walls and contains two new classes: Photobacteria and Scotobacteria. The class Photobacteria is divided into two subclasses: Oxyphotobacteriae and Anoxyphotobacteriae. The subclass Oxyphotobacteriae would comprise two orders: Cyanobacteriales (ordo nov.) and Prochlorales Lewin 1977 (6).

According to Rule 15 of the 1976 revision of the International Code of Nomenclature of Bacteria (4), "For each named taxon of the various taxonomic categories (listed below), there shall be designated a nomenclatural type." The taxa listed in Table 2 (p. 18 of reference 4) range from species to class. The types proposed are as follows: division Gracilicutes, class Photobacteria, subclass Oxyphotobacteria, and order Cyanobacteriales.

Two nomenclatural problems arise from the proposals outlined above, and opinions are requested to resolve them. These are as follows.

(i) The type of an order is the "genus on whose name the higher taxon is based" (see p. 18 of reference 4$)$. But the cyanobacteria $(10,11)$ have been considered as plants until recent

† Deceased, 10 December 1977. times, and a genus "Cyanobacterium" is unknown, although there are several with the prefix "cyano," e.g., Cyanococcus Hansgirg 1905, 521 (3). Names such as Cyanophyta Steinecke 1931 (12) and Cyanophyceae Sachs 1874 (9) are well known but are used for the rank of phylum and class, respectively. With the proposed classification, these become synonyms of the order Cyanobacteriales as used by Gibbons and Murray (2). The only genus of cyanobacteria with the suffix implying bacterium is the recently described Gloeobacter Rippka, Waterbury, and Cohen-Bazire 1974, 435. However, this genus is not representative of the blue-green bacteria as a whole as it does not contain thylakoids. Furthermore, the prefix "glois" (gelatinous, viscid) does not describe the whole order as effectively as does the prefix "cyano."

Other current names of blue-green bacteria are also inappropriate to construct a new ordinal name because the existing botanical class includes orders that might cause nomenclatural confusion with the present proposal to rank the cyanobacteria as an order rather than a higher taxon.

R. Y. Stanier was one of the first to use the term cyanobacteria and stress the relation of these organisms to other bacteria $(10,11)$. Although Lewin (5) has made objections to such a change and would prefer to retain the name Cyanophyceae on the basis of priority, it would seem that this would only continue the confusion. A name is needed that parallels this timehonored designation, that is readily understood, 
and that is expressive. We therefore request that the name Cyanobacteriales Stanier in Gibbons and Murray 1978 be made a correct, validly published, and legitimate name.

(ii) A second problem concerns the proper ending for taxa above the rank of order. Rule 7 (4) indicates that the names of taxa above the rank of genus are of the feminine gender. Rule 8 , which deals with taxa above the rank of order, does not indicate that the feminine gender is a requirement. In fact, one of the examples given, Schizomycetes, is masculine. Considering the variety of endings already required for the lower taxa and in the interest of simplicity, it is requested that the neuter plural endings, as proposed by Gibbons and Murray (2) for Photobacteria and Scotobacteria, be accepted as valid and legitimate endings for the rank of class.

\section{REPRINT REQUESTS}

Address reprint requests to: Dr. R. G. E. Murray, Department of Bacteriology and Immunology, University of Western Ontario, London, Ontario, Canada N6A 5C1.

\section{LITERATURE CITED}

1. Edward, D. G. ff., and E. A. Freundt. 1967. Proposal for Mollicutes as the name of the class established for the Order Mycoplasmatales. Int. J. Syst. Bacteriol. 17:267-268.

2. Gibbons, N. E., and R. G. E. Murray. 1978. Proposals concerning the higher taxa of bacteria. Int. J. Syst. Bacteriol. 28:1-6.

3. Hansgirg, A. 1905. Grundzüge der Algenflora von Nieder österreich. Beih. Botan. Zbl. Abt. 2. 18:417-522.

4. Lapage, S. P., P. H. A. Sneath, E. F. Lessel, V. B. D. Skerman, H. P. R. Seeliger, and W. A. Clark (ed.). 1975. International code of nomenclature of bacteria 1976 revision. American Society for Microbiology, Washington, D.C

5. Lewin, R. A. 1976. Naming the blue-greens. Nature (London) 259:360.

6. Lewin, R. A. 1977. Prochloron, type genus of the Prochlorophyta. Phycologia 16:217.

7. Murray, R. G. E. 1968 . Microbial structure as an aid to microbial classification and taxonomy. Spisy Prirodoved. Fak. Univ. J. E. Purkyne Brne 43:245-252.

8. Rippka, R., J. Waterbury, and G. Cohen-Bazire. 1974. A cyanobacterium which lacks thylakoids. Arch. Microbiol. 100:419-436.

9. Sachs, J. 1874. Lehrbuch der Botanik, 4th ed. W. Engelmann, Leipzig.

10. Stanier, R. Y. 1974. Division I. The Cyanobacteria, p. 22. In R. E. Buchanan and N. E. Gibbons (ed.), Bergey's manual of determinative bacteriology. The Williams \& Wilkins Co., Baltimore.

11. Stanier, R. Y., and G. Cohen-Bazire. 1977. Phototrophic procaryotes: the cyanobacteria. Annu. Rev. Microbiol. 31:225-274.

12. Steinecke, F. 1931. Die Phylogenie der Algen. Schr. Königb. Gelehrt. Gesamte Naturw. Kl. 8:127-297. 